\title{
The Preservation of National Childbirth Traditions in the Russian Homebirth Community (1) \\ Ekaterina Belousova
}

In Russia labor and birth were transferred from home to hospital shortly after the 1917 Revolution. A set of measures intended to promote state hospitals and reduce the authority of traditional birth attendants and healers was introduced. As a result, birth in hospitals became the norm, and the tradition of home midwifery was interrupted.(2) As the setting of birth changed, the ritual practices and physical treatments of homebirth were forgotten. Though hospital maternity practices preserved the essential archetypal structure of birth as a rite of passage [Belousova 2001], the traditional actions associated with birth disappeared. The practical experience of traditional midwifery was neglected and it was not integrated into the new tradition.

Another reason for these events was general change in the perception of the laws ruling the world, of human nature and, as a consequence, the organization of the human body. The Soviet authorities heavily promoted a positivist and materialist manner of thinking. The new mentality was secular, with atheism promoted by the Communists in mass media, school and workplace. The destruction of churches and severe repression of the clergy were part of the war against any perceived threat to materialist thinking. In fact, Russian popular faith presented a complex phenomenon, a mix of Russian Orthodox and pagan elements. People often considered pagan rituals and beliefs as Christian and experienced difficulty in differentiating one from the other. State ideology decried pagan customs as superstition and those who practiced them were persecuted.

The private life of Soviet citizens was generally scorned and ignored. The limits of the family were far from hermetic; the Communist Party had the right to regulate the life of the

family, approve marriages and divorce proceedings, discuss cases of adultery in public and recommend models for the proper organization of family life. Childbirth, too, was treated as a public event, given that it related to the appearance and upbringing of a new citizen, who was expected to perform certain functions within the social system. Maternity leave was brief and within two months babies were sent to baby-care units to be reared in accordance with the principles of a communist upbringing.

Positivist thinking became dominant in medicine as well. The psychic and spiritual dimensions of illness were rejected; only the body was treated. Consequently, biomedical 
techniques formed the basis of treatment. The separation of medical knowledge into specialisms furthered the treatment of particular organs in isolation, while the links between bodily functions were ignored. Holistic attitudes in healing, presupposing a view of the person as a whole came to be regarded as irrelevant. The mechanistic view of the human body promoted the idea of a norm and deviations from it. The process of birth was now regarded as a predictable mechanical process requiring standardized interventions in the case of deviations from the norm. Thus, routine medical stimulation of birth, amniotomies and episiotomies became the norm in hospitals.

In spite of all the restrictions and prosecutions, Russian Orthodoxy, traditional healing and folk beliefs were preserved on the fringes of Soviet society. Grannies baptized babies in secret and taught them the main prayers and basic tenets of Christianity. On occasion people would consult traditional healers in the countryside. A black cat crossing the road caused fear and was perceived as a sign of trouble ahead. The biography of an individual could be seen as a sequence of mystically connected events. Superstitious beliefs managed to coexist peacefully in the popular consciousness along with a rationalist frame of mind. Traditional knowledge preserved its authoritative status, and was even used to support new scientific discoveries [Ovchinnikova 1998: 233-35]

The history of the homebirth movement in Russia has been influenced by political, economical and social developments. 1980 marks its beginning, when the marginal scholar Igor Charkovskii, accompanied by a small group of people, arranged for four water deliveries in two specially designed glass pools in a Moscow apartment [Martynova 5:2]. After that, more and more people became involved in the family club known as "Zdorovaia Sem'ia" (Healthy Family). They began giving birth at home on their own or with people experienced in homebirth in attendance. They also promoted alternative patterns of health treatment and childrearing.

In the early 1980's homebirth was an underground dissident movement. In the first place, for both individual and his or her family this was a struggle for privacy. Homebirth adepts claimed that they did not want to share responsibility for their own health and family life with state institutions like antenatal clinics, hospitals, baby care units and schools. They called their philosophy soznatel'noe roditel'stvo (conscious parenthood). Birth and childrearing were supposedly special events in the life cycle of the family. Unassisted birth was their ideal. People already experienced in helping others in birth would work free of charge. Proselytism and dissemination of information about the benefits of homebirth was an important part of their activity. 
An additional issue in the ideology of homebirth was the rehabilitation of the spiritual dimension of human life. Homebirth agents viewed the human body as closely connected with psychological processes and spirituality. In the early days, the spiritual dimension of birth possessed an eclectic character. Childbirth customs from many different world traditions were garnered from sources of varying reliability and deliberately combined by those propagating homebirth:

In their minds it's total confusion. Some things they remember and some things they've read somewhere, but this knowledge is anything but systematic. For example, they read some kind of medical literature about the placenta, and it's mentioned there that in folk belief the placenta is used as an amulet. So they say: "Wow! We have to tell people about this, we must share this information!" So everything [their knowledge] is based on jumbled facts. [Alla]

At this point in time elements of Russian Orthodox rites coexisted in homebirth practice along with pagan Russian beliefs, myths taken from various primitive societies, Yoga, Zen-Buddhism and transpersonal psychology. This kind of "basic spirituality" is characteristic of a New Age paradigm. Combining these myths with rational scientific data, homebirth proponents formulated a complex system of humanity, the human body and bodily processes. Childbirth was considered an important event along the spiritual path of the baby and of the family as a whole. Thus social institutions should not intervene, since they would ruin the spiritual experience. Lay birth assistance acquired the name of dukhovnoe akusherstvo (spiritual midwifery) in the homebirth community, since it focused on the spiritual guidance of parents.

The third important theme in the ideology of homebirth was connected with ecology. As opposed to the common "profane" vision of personality as a unit of the state, homebirth agents suggested that humans belonged to the natural world and were responsible for its well-being. In this system, humans were seen as deeply integrated into "natural" processes and connections. The human body was considered cosmically oriented and axiologically heterogeneous, in possession of certain special organs and bodily functions responsible for cosmic communication. Human beings had to support the world by maintaining "natural" connections with it, as well as by avoiding and preventing any "artificial" ones. They were supposed to develop extra-sensory abilities to allow them to communicate with the natural world on different levels. Parents were to bring up a new generation capable of resisting the destruction of the world and nature as a result of various inversions of "natural" processes, pollution and nuclear war. The keyword in the 
homebirth group's self-representation discourse was "natural," as in the term estestvennye rody (natural childbirth).

This variant of homebirth ideology was especially relevant in the totalitarian context of the Soviet Union. The hybrid multicultural character of homebirth mythology, worries about the fate of the Earth, and interest in similar processes in the West were characteristic of Soviet homebirth ideologists, who saw themselves in the context of an immense multinational country.

In late 1980s and early 1990s, during perestroika, eschatological expectations among the public generally increased, and discussion about impending disintegration and collapse in all the spheres of life (pollution, radiation, medicine, education, business and finance, agriculture, railroads etc.) was widespread.(3) These attitudes provided additional support to the ecological myth propounded by homebirth supporters.

At the same time, people now felt they could ask for supernatural help. Mass baptism and the rehabilitation of the Russian Orthodox faith was characteristic of perestroika, as well as interest in magic and in psychic phenomena. Healers, sorcerers, astrologists and hypnotists became extremely popular. The most popular, such as Anatolii Kashpirovskii and Alan Chumak, used to address the whole country and offer healing on national television. Private business became legal, and numerous small publishers and newspapers began specializing in books on dreams, the interpretation of omens, folk healing and the supernatural.

These changes in popular consciousness drew people to homebirth thanks to its concern with spirituality. In the early 1990's the first "parenting schools" were set up. By that time some of the people involved in homebirth had turned professional. Now that private business was legal, they were entitled to set up their own schools. Officially, these were only allowed to teach "pregnant couples" how to give birth in accordance with their views on childbirth, since assistance at homebirths was still prohibited by the state. In fact, "instructors" at these schools also assisted illegally at home deliveries.

The very first parenting schools preserved the initial tendency towards a multicultural approach to homebirth. "Instructors" in the schools taught future parents "oriental" philosophical and mythological concepts and ritual practices (e.g._chakras, karma, mantras etc.). These notions, inevitably reinterpreted, coexisted peacefully in their worldview along with their interpretation of Russian traditional customs and modern science. Their special interest in ecology and the preservation of the natural world was reflected in the names of the schools: "Ecologiia Sem'i" (Family Ecology), “Akva” (Aqua, supposedly suggesting waterbirth), “Akva-Marina” (a pun on 
sea birth and the name of the school's head, Marina Dadasheva), "Pangea" (connoting the chthonic aspect of the birth myth). Homebirth adepts paid a great deal of attention to homebirth movements in the West. Now that contacts with the West were easier to establish, they sought out, translated and published works by western homebirth and waterbirth pioneers, all the while incorporating much of their practices into their own work. Thus, Grantly Dick-Read, Frederick Leboyer, Michel Odent, Ina May Gaskin, Sondra Ray and other proponents of alternative childbirth became authoritative figures in the Russian homebirth community [Dik Rid 1997; Leboie 1988; Oden 1994; Gaskin 1986; Rei 1985].

The homebirth dissident movement little by little transformed itself into a business. At present, about twenty licensed parenting schools are operating in Moscow, while St Petersburg has five. There are parenting schools in Tver, Nizhnii Novgorod, Ekaterinburg, Novosibirsk, Khabarovsk, Vladivostok and many other large Russian cities. Parenting schools have developed their own special courses on "conscious conception", pregnancy, childbirth and the early development of children. Rates for these courses vary. For example, in Moscow a course on pregnancy and childbirth usually ranges from $\$ 100-350$. The fee for assistance in childbirth is flexible and depends on the financial situation of the family (typically \$200-500).(3) The schools are now perceived as providing a distinct range of services. The emerging middle class has joined the artists and intellectuals who were the initial target group for "natural childbirth" educators.

The fall of the Soviet Union was a crucial point in the construction of Russian national identity. The internationalist conception of the Soviet State as a "family of peoples" was no longer relevant. Russian nationalist and fundamentalist movements appeared on the scene and gathered strength. Russian national identity was accompanied by the rehabilitation and revitalization of the Russian Orthodox Church and Christian traditions. References to Russian peasants and the Slavs of old as "our ancestors" were often to be heard in Russian nationalist discourse.

These processes deeply influenced homebirth ideology. In the mid-1990's a new trend appeared in the homebirth movement: "Russian Orthodox" midwifery. Some midwives who had previously venerated nature and practiced eclectic traditional customs reinterpreted their vision of childbirth and midwifery, such that Russian Orthodox principles and traditions became the central focus of their work. Professor N. Zharkin, the head of an experimental clinic in Volgograd, has been practicing waterbirth since 1996 and identifies his activity as "spiritual midwifery". He 
comments as follows on the main principles of "Russian Orthodox" understanding of the birth process:

Our experience demonstrates that the rehabilitation of Russian Orthodox traditions of childbearing underpins the provision of not only gentle, but even enjoyable childbirth (partus felix), one that leaves a permanent impression on the hearts and minds of mothers, babies, fathers and anyone witnessing the event. These traditions include a lot of elements, but the most important are the following: love and trust in God; a prayer to the Mother of God, who protects mothers in childbirth; releasing; that a child, while not yet born, belongs to God and that she or he already has a soul that is able to experience all the human feelings of joy, pain, fear and so on. This is a perception of childbirth like the miracle of the Savior's birth, that is the birth of the Savior of Her maternity (sic), which is repeated in every mother. And when the mother's soul unites with the baby's in childbirth, and both are protected by the veil of the Mother of God, it is hard to imagine that any kind of medical complications might occur. [Zharkin]

Appeals to the power of nature were therefore now interpreted as sinful and dangerous. "You shouldn't ask for health from - who knows what - from [an uncertain] 'nature'!" said Liudmila Vasil'evna, the leader of the "Kupel"” (Font) parenting school in St Petersburg. "Oriental” practices and terms were rejected and claimed as harmful when used by Russians. Zharkin tells the following story concerning the danger of applying "oriental" practices to those with an "Russian Orthodox mentality":

A Russian Orthodox woman was due to give birth to her second child. She was advised by her midwife to attend classes in a group practicing transcendental meditation. There she was given a mantra for meditation. The medical record of her pregnancy showed nothing unusual, nothing out of the ordinary. She had had no problems giving birth to her first baby. Her current pregnancy also developed initially without any problems. Only in the last month did she start to feel a general weakness that got worse. She didn't go into labor on the due date, and there were indications of fetal postmaturity. So she roomed in our clinic to speed the start of labor. Pharmacological treatment and acupuncture, normally effective when applied together, didn't have any effect in her case. As she'd reached forty two weeks and there still were no indications that she was ready to give birth, the question of Cesarean section arose. In the course of further conversation, details of her [new] spiritual practice came to light, something the patient 
had not mentioned previously. With her approval a priest was summoned to take her confession, during which she revealed the mantra. He advised her to pray with all her heart to the Mother of God, which she did. Labor started the next day without it having to be induced, and finally she gave birth to a healthy baby. [Zharkin].

Some of the adherents of "Russian Orthodox" midwifery insist on the primacy of Russian tradition on Russian soil, at the same time rejecting any suggestion that the traditions of other peoples inhabiting Russia equally merit preservation. Ultimately, it was the "consolidation of the Russian (or the Russian Orthodox) family" that was proclaimed as the new task for the homebirth movement, since it would result in the "restoration of Russia" itself:

Once a doctor came for a home visit. He was a Jewish guy. He saw those kids who'd been delivered at home, and he said: "If everybody gave birth at home, we would see Russia reborn. " [Oleg]

The main thing is to preserve the family, bring people to the faith, and restore Russia. Let children be devoted to the Russian soil. May parents love their children, children their parents, and all of them love Russia. Then Russia will truly exist. [Liudmila Vasil'evna]

The main focus of our club is on the reinforcement of the family, so that it will not be destroyed but instead expand with strong and healthy children, and so that families will preserve the spirit of Russian Orthodoxy... We want to see people and organizations who care about the survival and consolidation of the Russian family. [Stepanova 2001] As a result, waterbirth and infant swimming needed Orthodox supportive material as well. Homebirth ideologists began to associate their practices with the healing power of baptism. The founder of the movement, Igor Charkovskii, recently expressed the view that "Russian Orthodox culture is more developed than western. According to Russian Orthodox custom, the baby is immersed in water on the eighth or ninth day of his or her life. The mystery of baptism solves a baby's health problems better than any medical discovery. [Charkovskii 1999]. In fact, for many of the parents attracted by "natural childbirth," it was precisely the Russian Orthodox flavor of parenting schools that turned them into supporters of homebirth.

Along with Church tradition, numerous pagan Russian childbirth practices have been adopted, widely used and a rational explanation for them sought, because midwives were not really aware of their pagan character and believed them Christian. In reality, the rural midwife was an ambivalent figure in traditional Russian culture. On one hand, midwives were perceived 
as witches, possessing supernatural power and having contacts with demonic forces [Kabakova 2001: 76]. They used spells and magic widely during childbirth. Midwives voluntarily acquired marginal status in society. By attending births, they shared the alleged impurity of the birth process [Levin 1991].

However, traditional midwives often denied that they possessed supernatural powers, practised magic or made contact with the powers of evil. They were perceived as mediators between the woman in labor and the heavenly powers [Listova 1989: 146]. They largely used Christian objects such as the cross, icons, holy water and myrrh along with Russian Orthodox prayers. The extreme piety of midwives has been widely noted.

Contemporary "Russian Orthodox" midwives are perceived as dealing with heavenly forces. Although special psychic abilities are often ascribed to them, there is a tendency to speak about these in Christian code. Since dealing with "unknown forces" and supernatural phenomena is perceived as sinful and dangerous, it is necessary to reject the idea of the midwife possessing inner supernatural abilities and ascribe them instead to divine guidance.

The midwife's entry into the profession is seen as a result of heavenly guidance, a gradual recognition on the part of the midwife of her spiritual calling. Midwives interpret events in their lives as signs from heaven indicating the necessity of leaving their current profession to begin offering a service to people:

Much later, when I already felt I was being guided from above, I began to understand that my own baby was sent to me from Heaven, a gift. The Lord presented me with this child as a reward, because I had succeeded in understanding my mission on earth, even though at that time I hadn't been baptized. I appeared able to understand what God wanted me to do. He led me towards gentle, natural childbirth, and I was capable of listening... I was due in about four or five weeks at that time. It meant that conception had taken place in April, right after the first baby I had delivered myself! What a surprising coincidence! Later I understood that the Lord had given me this gift because I had chosen the activity, for which I had been sent to this world... On January 8, I gave birth to a little girl, who was later given the name of Anna, in accordance with my grandmother's wishes. Much later I learned that 8 January was a holiday: Midwife's Day! And now my [daughter] Anna is studying midwifery, too. [Martynova 10: 3]. Midwives associate themselves with the podvizhnitsa (holy laborer), describing their work as sluzhenie (service). They claim they do not care when, or even whether, they are paid by the 
parents they have assisted. "It's okay, God will take care of me," said Irina Martynova. Liudmila Vasil'evna emphasized that the main reward a midwife gets is when parents mention her in their prayers.

A "Russian Orthodox" midwife is supposed to obtain a priest's blessing before assisting at a childbirth. Practicing midwifery without such a blessing is seen as improper because births in this case lack supportive protection:

You must have a priest's blessing to be a midwife. I did. Liudmila Vasil'evna, Ol'ga Ivanovna and Alena did, but Lena Ermakova - she didn't. She works somewhat in the American style [Irina Martynova, home midwife] Although midwives of this kind sometimes look after people not belonging to the Russian Orthodox Church, they strongly prefer to work with Russian Orthodox. "It is easier to work with people, who 'speak the same language,"' said Natal'ia, a specialist in the teaching of children at the "Rozhdestvo" (Nativity) parenting school. Irina Martynova explained that a Christian outlook is supportive during birth, as pride (gordynia), regarded as a grave sin in the Christian religion, prevents parents from having feelings helpful during labor, in particular complete penitence and humility, which are seen as essential for easy dilation and coping with labor pains. Marina Dadasheva has claimed that working with unbaptized people is harmful to midwives. When this happens, she might be tempted to ascribe her success to her own skills and not to God, something she recognizes as sinful pride on her part:

Sometimes you deliver a baby and come home quite pleased with yourself, but then everything starts going wrong, in your own family and so on. The reason has to be pride. That is why I prefer not to deal with unbaptized babies. Today I was going to work with a sick child. I asked the mother to have him baptized by today. But she didn't do it. So I had to delay the session, and wait until the baby has been baptized. Humility brings peace to the soul.

A pregnant woman must receive absolution, communion and a priest's blessing before childbirth. This is believed necessary to make labor easier for the woman since "God is punishing a woman in labor for all her sins" [Anna]:

First, we devote a lot of time [at our prenatal classes] to talking about faith, the divine channel of communication and Christianity. Communion and confession are essential before childbirth. They really act as a form of purification before birth; they should take place. And the mystery of confession, of course, gives a lot to a woman. She comes to 
the birth without fear, or pain in her body (I mean, spiritual pain). [Marina Dadasheva, home midwife].

Absolution and communion are also supposed to protect the baby from sharing the mother's psychological problems:

Before I was due, I went to church and confessed so that the baby would arrive in this world without any problems - at least, without my problems... So as he wouldn't share my problems. I didn't want him to have any problems; that he might live in peace, live his own life, and follow his own fate. [Ira]

The birth of babies with mental and physical disabilities traditionally brought into question the mothers' behavior. When such children were born, the mother was asked how she had sinned [Bernshtam 2001: 103]. Significantly, it was believed that God chose a punishment that corresponded to the sin. Irina Martynova, a midwife, commented on the birth of the baby with Down syndrome as follows:

I think that the woman's job was involved. It was a sign from God. This woman worked in a psychiatric clinic, and particularly with Down syndrome children. Then she herself gave birth to a Down child. Maybe, there was something she did wrong when she was working there. Maybe she treated her patients badly. That's how it goes: the way you sin, that's the way you'll be punished. [Martynova 71: 9].

It is considered important for a mother-to-be to ask her relatives to forgive her and for her to forgive others (prosit' proshcheniia; prostit'). This practice used to be widespread in traditional Russian childbirth ritual. Although it reflects Christian values, it is not part of Church doctrine. Contemporary midwives propose a rational explanation of this practice. It is explained as promoting dilation, as it supposedly allays the woman's anxieties and thus encourages her to relax:

You know, one of the customs is spiritual purification before birth. I mean, forgiving any offenses you've caused and asking people to forgive you. There is something similar in Russian Orthodox tradition. I don't think it's just a rite. People say it's difficult giving birth without it. It can easily be explained from a psychological point of view. [Birthing without forgiving] prevents a woman from giving birth normally, from proper dilation. And, most of all, resenting the man, the father [is harmful]. [Svetlana Abramova, the director of "Zhemchuzhinka" (Pearl) parenting school] 
The ritual also has other less rational explanations. There is a tendency to trace superstitious connections between life events, such that forgiveness provides for a successful birth, because secrets between spouses may result in health problems and even the death of the baby:

Her [midwife's] main idea is as follows: "A woman gives birth the same way she lives in general." You should solve your family problems before birth. Once there was a woman who had had lots of abortions and hadn't told her husband about them, and her baby died in birth. [Ksenia]

Another important Russian traditional practice was for the woman in labor to say farewell (proshchat'sia) to her relatives and neighbors as well as to cosmic entities, such as the sun and the night. In the past this formula is said to have initiated the birth ritual [Vlaskina 2001: 65]. As a rite of passage, childbirth ritual suggests the symbolic death of the mother. Thus, saying farewell here echoes the funeral ritual. Today death symbols are also incorporated into views on childbirth: "Father Vladimir Tsvetkov usually says that you should prepare for labor and birth like you would for death" [Liudmila Vasil'evna].

The Orthodox Church has an ambivalent attitude to homebirth. However, there are priests sympathetic to it, and who support particular parenting schools. Whenever possible, a priest is invited to bless the place where the birth will occur. The room is cleaned and purified and icons, icon lamps and candles put in place. The priest hears the parents' confessions and blesses them: Right before the birth the priest came to see me. He heard my confession again, and my husband's as well. There were lots of icons in the bathroom, as well as in the room where we were with the little one after the birth. It was a kind of coincidence: before all that I didn't believe... I mean... Everybody has their own personal God, more or less close to them. But these events changed everything. It was as if I'd been hypnotized. And the priest prayed too. And said: "Don't be afraid of anything”... I wasn't worried about the possibility of infection, as the water had been blessed. [Ira]

The priest's blessing during the birth is reported to help women with difficult labors and give them extra strength:

Once I saw a woman in labor. Before the blessing she was practically fainting. She clearly wasn't going to be able to cope. She looked so pale, almost blue... Then the priest came and sanctified the bathtub with holy water. The girl sat up straight, she did, and gave birth five minutes later. [Natasha] 
"Russian Orthodox" midwives pray during childbirth. It is said that midwives' prayers "reach their destination" [Ekaterina cited by Vika]. Prayer is considered "a powerful therapeutic device" [Natalia]. Certain saints are the patron saints of childbirth, and some specific icons are seen as especially supportive, particularly those depicting the Virgin Mary. Thus the icon “Bogoroditsa Feodorovskaia” (Feodorovskaia Mother of God) supports maternity; "Pomoshch' v rodakh" (Help in Giving Birth) protects women in labor; "Znamenie" (Our Lady of the Sign) helps prevent the umbilical cord getting entangled; and "Mlekopitatel'nitsa" (Milk-Giver) promotes successful breast-feeding. Praying to the icon of St. Virinea helps to prevent postpartum hemorrhage. St. Nicholas is believed to protect people in and on water, relevant in the case of waterbirth. St. Panteleimon the Healer cures medical problems in general, and as well as those related to birth. Other female saints such as Sts. Anastasia, Catherine and Barbara are still the patron saints of women and birth, just as they used to be in traditional Russian culture [Popov 1996: 443; Naumenko 1998: 28; Nekrylova 2000: 58; Bernshtam 2000: 101]. Paraskeva-Piatnitsa was especially venerated in traditional Russian society as the patron saint of female activities, marriage and childbirth. Paraskeva-Piatnitsa is the Christian "successor" to the pagan Slavic goddess, Mokosh' [Slashchev 1995; Ivanov and Toporov 1982; Ivanov and Toporov 1995b]. In Russian folklore Paraskeva is sometimes presented as a rural midwife [Maksimov 1994: 426427]. Nowadays Paraskeva-Piatnitsa is considered the patron saint of midwifery, and her icons are used in homebirth:

By then, her older daughter, Masha, had painted and presented me with an icon of Paraskeva-Piatnitsa, the patron saint of my service... I knew this saint looked after me in my work, and for ages I'd been dreaming of getting her image to have with me when I go off to attend women in birth. And so the Lord gave me the icon of ParaskevaPiatnitsa via this family who painted icons, through these Russian Orthodox connections. [Martynova 11:4]

Thus "Russian Orthodox" midwives bring special icons to the birthplace to help them in their work. Ksenia, who is not a Christian, says of her midwife, "She uses particular icons and prayers, which help her to go deep into the birth process. She is a magician, and these are her magic objects."

The parents also pray during labor, and their relatives go to church to pray for a safe delivery, and there write the mother's name on the liturgical prayer lists. One Old-Believer mother said that she and her husband used to recite spiritual verses during childbirth, in a 
somewhat ecstatic manner, something taken seriously amiss by their "Russian Orthodox" midwife:

We did everything differently. We shouted: "Theotokos, have mercy on me!" (Bogoroditse, pomilui!) and so on. Oleg recited various canons. It was all on a religious basis. The bathroom was full of icons; all the candles were lit... And during labor I kept shouting, not "mommy, mommy!" but “Theotokos, have mercy on me!” So there really was special energy around. And when I gave birth, I suddenly broke into song. I had suddenly acquired a voice - an absolutely splendid one. And with all my strength I began singing spiritual verses and prayers. Our midwife nearly fainted. [Natasha]

After the baby has been born, the midwife is expected to perform the ritual ablution (omovenie). In the early stages of the "natural childbirth" movement, considerable emphasis was placed on the positive physiological effects of water procedures in general and pouring cold water on the baby (oblivanie) in particular. This action supposedly stimulated the bodily mechanisms responsible for thermoregulation. This effect is still acknowledged by midwives. However, now the stress is on its religious and ritual aspects, bearing in mind that in Russian traditional culture rural midwives practiced pogruzhenie (immersion) of the baby for protective purposes [Dobrovol'skaia 1998: 20; Kuz'muk 1998: 18; Vlaskina 1998: 16]. While praying, the contemporary midwife pours some holy water into a bucket of regular water. She then says "In the Name of the Father, the Son and the Holy Spirit," pours some water over the baby's head and body, and immerses the baby's feet in the bucket of water. Then she pours all the water in the bucket over the baby and says "Amen."

In some cases, in the absence of a priest, rural midwives performed a ritual known as povitusheskoe kreshchenie (the midwife baptism ceremony) [Listova 1989: 148-49]. It involved reading some special prayers and naming the baby. Nowadays some of the "Russian Orthodox" midwives have been blessed by their confessors and allowed to perform this ritual:

Babies are baptized straight after birth, using holy water. She's been given the priest's blessing for this. She recites a prayer, pronounces the name right away, and pours a bucket of ice-cold water over the baby. When you give birth, she [the midwife] turns off the light, not like in hospitals, where there are incredibly bright lights. Here there are only candles, icons and icon lamps. Everything is pure and blessed. [Alina] This ritual is considered an emergency baptism, no substitute for the actual ceremony. It is assumed that the baby will be baptized again later in church. However, after this ritual has been 
performed, the baby is considered protected during the period before the real baptismal ceremony takes place. The "midwife baptism ceremony" is especially relevant in cases where the baby's life is in doubt. If the baby dies before official baptism by a priest, a Church funeral service can still be held, because the child has already been christened by the midwife.

According to church doctrine, as well as in the popular beliefs of many societies, postpartum blood flow made women ritually impure [Listova 1996]. Consequently, there were certain church and popular traditions that imposed special prohibitions on the mother and those who attended the birth. There were also rituals of purification reintegrating ritually impure people into the community. Since the tradition of having babies at home had been abandoned, contemporary liturgical books do not contain prayers for the purification of the house, the midwife, or those present at the birth. When homebirth established itself as a tradition related to Russian Orthodoxy, the need arose for prayers of this kind. A Petersburg priest who favors homebirth, Father Vladimir Tsvetkov, found in the archives a mass written in 1651 by Patriarch Iosif, containing a special cycle of eight prayers for the purification of the place where a birth has occurred, of the midwife, new mother, the people who have attended the birth and the baby when first laid in a cradle. Now some priests supporting homebirth use these prayers on a regular basis.

In Russia, as elsewhere in the Christian world, a new mother was prohibited from entering the church for forty days. This tradition is alive today, with the new mother being purified on the fortieth day when the baby is baptized. Together with this period of time, there was also a tendency towards baptizing babies as early as possible, usually from three to nine days after birth, given that so many died very young. By contrast today, the baptismal ceremony is often delayed until the baby is several months old.

There are also many pagan and quasi-pagan magic practices and techniques used in home midwifery, though the midwives generally view these as Christian. Therefore, their beliefs can be compared to those of Russian women in the past, who were adepts of a popular Christianity that was a mixture of Russian Orthodox and pagan beliefs [Levin 1991]. Midwives use herbs and potions, rather than allopathic medicines in their practices. They also encourage women to use amulets. At parenting classes pregnant women are taught to sew baby shirts with Russian traditional decorations, which are, in fact, old pagan symbols intended to ensure by magical means the baby's health and well-being: 
I also used to embroider little motifs on Niutka's clothes: a baby hat and a diaper. They showed us how to do it. These are our specifically Russian motifs - milk rivers with jelly (kisel'nye) shores. So that you have plenty of milk. And then you have to sew little shoots and flowers, so that the baby shoots up. All kind of ancient Russian motifs. It is fun. This diaper hung over Aniutka's little bed for ages, the diaper and the baby hat. [Katia]

And in all this mess there I was sitting and embroidering a baby shirt with all those solar symbols. And I got really miserable about it. What happens if I don't do it? They [the childbirth instructors] just take it for granted you're going to stop wearing T-shirts, embroider a Russian shirt with motifs, if possible get baptized, and then everything will be okay. [Vika]

The names of parenting schools often use Christian symbols: "Rozhdestvo" (nativity), "Blagovest" (a peal of bells, the word has the same root as Blagoveshchenie (Annunciation), and therefore the name of the school connotes the Christian contexts of childbirth), "Kupel" (font, presenting the idea of waterbirth in terms of baptism). However, some schools also have names pagan in origin but reinterpreted from a Christian standpoint. For example, one of the Petersburg parenting schools is called "Bereginia." The word "beregini" referred to multiple pagan female deities and has been interpreted etymologically by different ethnographers to mean water, hill or mountain spirits [Tolstoi 1995; Ivanov and Toporov 1995a]. However, the word was adopted by this school's founders in the singular, and re-etymologized to suggest it came from "berech" (to take care of). The school's director, Ol'ga Vinogradova, rejects any connection between the name and pagan deities and interprets it as an epithet applied to the Mother of God, who is believed to care for pregnant women and mothers in childbirth. Zhanna Tsaregradskaia, the founder of "Rozhana" parenting center, interprets their name as a "Slavic" word meaning a woman in labor. In fact, it recalls the word rozhanitsy, a term applied in pre-Christian Russia to pagan deities associated with childbirth [Ivanov and Toporov 1995c].

The bathhouse was the traditional location for the delivery of babies. It was perceived as an axiologically special place, possessing both sacred [Baranov 2001:15-16] and demonic connotations at the same time. In Russia it was here that Yuletide divination took place. It was supposedly dangerous for a woman with liminal status (such as during labor and for forty days after the birth of the baby) to go to the bathhouse alone. She might be suffocated (zadavit') by an evil spirit, and her baby replaced with a changeling (podmenysh). As childbirth was seen as the 
mother's journey to an "alien" world, it had to be symbolically established in the spatial code of the ritual. As the symbolic representation of that "alien" world, the bathhouse was perceived as a distant place, even though it was located near the house.

It would appear that contemporary bathhouses do not possess demonic connotations in the homebirth community, being associated instead with purification. The future mother's soul must be purified through confession and communion. In addition, she is physically purified in the steam of the bathhouse. As Ira put it: "We also went to a bathhouse in Ozerki. Spiritual preparation takes place in church, and physical preparation, in the bathhouse." Midwives rent rooms in public bathhouses for several hours a week and here meet the pregnant women in their care. Some of the midwives also use the bathhouse as a place where their clients can listen to lectures, do exercises, share problems and receive regular checkups. However others claim that preparatory classes should not interfere with the true purpose of the bathhouse. They suggest that bathhouses should be used for purification procedures, communication and relaxation:

They also arrange checkups there in the bathhouse. I'm opposed to that. In a bathhouse you should stay relaxed. It should take an hour or so to do a careful checkup on one woman. How can that be fitted in? [Liudmila Vasil'evna, home midwife]

An expectant mother is supposed to go to the bathhouse as well as to church just before she is due to ensure she is pure in spirit and body. Since women cannot go to a public bathhouse and give birth, they generally use their own bathroom as the birthplace.

In the past rural midwives performed numerous magic practices to hasten dilation and make labor easier; for example, they recommended that women in labor unplait their hair, untie any knots in ribbons and belts, and unfasten any clasps [Firsov and Kiseleva 1993: 139-40].(4) This loosening, unplaiting and unbinding symbolically represents the "unbinding" of the uterus [Baiburin 1993: 94], corresponding to the release of the major reproductive forces on the macrocosmic level [Vlaskina 2001: 67]. They also opened anything normally kept closed, such as doors, windows, gates, locks and boxes, with the aim of helping the birth along [Naumenko 1998: 33]. While in the past these actions belonged in the domain of magic, today they are explained as psychological necessity. It is assumed that this ritual opening symbolically influences the unconscious of the woman, thus helping her to release the child:

Such a thing as untying knots, unplaiting the hair etc. works on the inner "clamps"... It works like an image, a myth, like entering some special space - unbinding those knots. I don't tell women that they necessarily have to open everything when they go into labor. 
I am not fanatical about these things. However, while I was attending one particular woman, I said [to her relatives]: "Go and open everything”. That woman had some kind of inner "clamp". [Sargunas 1998]

When they were in labor Russian village women were supposed to keep moving, walking around and changing position [Vlaskina 2001: 67]. One of the well-known means of hastening a prolonged labor was for the midwife to lead the woman around a table [Firsov and Kiseleva 1993: 140; Naumenko 1998: 33]. Contemporary midwives have preserved this technique. They explain that it produces an extended state of consciousness in the woman, considered helpful for the final delivery of the child. Vika notes that "her labor was prolonged, so to speed up the contractions they had her making circles around the room until she felt like she was inside a wheel."

The lithotomy position required in hospitals during delivery is not viewed as conducive to labor by home midwives. The traditional upright position is preferred. The necessity of remaining vertical during labor constituted an important element of the semiotics of labor. During the ritual the female body was viewed within a major cosmic context. The upright position put the woman in a symbolic relationship with God on the one hand and the earth on the other.(5) The supine position during labor was seen as physiologically harmful and ethically improper [Baranov 2001: 17-18]. Nowadays, semi-sitting and squatting positions during active labor are popular, and they are possible in a bathtub where most homebirths occur.

One interesting example of how contemporary midwives rework traditional ritual is folk singing with an "open voice," thought helpful for women in labor. It is said that if the woman sings this way, it helps hasten dilation, provides assistance in the second stage of labor, and helps the woman to cope psychologically with labor pains. Midwives present this technique simultaneously as an old tradition and a new discovery, one with both a physiological and a psychological basis:

We owe our contemporary state of knowledge about birth traditions and the possibility of using the voice to the Dmitrii Pokrovskii Ensemble. Based on the material collected on numerous folklore expeditions and what little has been written on the subject, a method of entering the birth process via the voice has been devised. It is unique in the contemporary civilized world. [Postnova]

The Dmitrii Pokrovskii Ensemble is a famous folk music group, whose repertoire was collected during numerous expeditions to Russian villages. Simultaneous citing the authority of tradition and science proved a very effective rhetorical device in post-Soviet Russia [Ovchinnikova 1998: 
235]. However, these songs were not initially designed for childbirth. An important element of the Russian birth ritual was that the woman had to keep silent, as she supposedly temporarily left the human world and, consequently, lost all human characteristics, including her voice [Sedakova 1999]. It was also believed that the fewer people who knew about a woman being in labor, the easier the birth would be. Thus, contemporary midwives incorporate traditional practices into new contexts, and simultaneously try to rationalize them.

Certain ritual actions are performed with the placenta and the umbilical cord after a baby is born. Igor Charkovskii calls the womb the "resonator of cosmic communication" [Akva: 33], while the midwife Tat'iana Sargunas calls the placenta "the cosmic aerial" [Tat'iana Sargunas, home midwife]. Normally, the cord is not cut off before the placenta has been delivered. Ideally the procedure is performed twenty-four hours after the birth. It is said that this delay ensures that the child receives the proper amount of cosmic energy from the placenta, which is regarded as a mediator through which energy is transferred from the universe. The placenta is put into a vase filled with water and kept near the baby. However, in fact the cord is often cut sooner for a variety of reasons:

Our ancestors, the Slavs, practiced waterbirth. They used to cut the cord at sunrise. The placenta, it's an energy generator, you know, and they were solar people... But we certainly have to fit in with our life today and our conditions. [Irina Martynova, home midwife]

Thus after a certain period of time the midwife ties the cord. The cord is bound three times with coarse thread. While tying the knots, the midwife says, "in the Name of the Father, the Son, and the Holy Spirit. Amen." Clamping the cord is regarded as harmful because it is believed to cause umbilical hernia. The baby's cord is specially wrapped in a kosynka (a three-cornered piece of cloth). When it dries and falls off, the parents usually keep it. Some midwives recommend keeping it in a ladanka (a small bag, containing sacred objects, worn as an amulet) together with a small icon of the baby's patron saint.

Although sometimes the midwife cuts the cord herself, the baby's father generally performs the procedure, which is supposedly a traditional custom. However, the data on traditional Russian childbirth reveals that this was something the midwife did. That it was her responsibility is reflected in the one of the traditional terms for the midwife, puporezka (the cord cutter). One of the traditional rituals that did actually involve the father was when the baby was 
wrapped in one of his old shirts [Popov 1996: 465-66; Baiburin 1993: 43-44; Kabakova 2001: 9799]. Nowadays both these actions are seen as a psychological as well as a physiological necessity: You see, I never practice any particular rituals, and I wouldn't advise anyone else to do so either. Wrapping the baby in the father's shirt just serves to transmit the father's [friendly] microflora to the baby. It just transmits to the baby the maternal and paternal energies and microflora. As for the cutting of the cord, I can see it's a very important symbolic thing for a man. It's such an important process... I can't explain why. I think it influences male psychological patterns; the very fact that he's been allowed to touch the baby, and even more, to take such a significant action. [Svetlana Abramova, Director, "Zhemchuzhinka" (Pearl) parenting school]

The husband's participation in contemporary homebirth procedures preserves certain aspects of the Russian traditional couvade ritual. A man was supposed to share his wife's pain, and a set of ritual practices existed, in which male labor pains were symbolically represented. $\mathrm{He}$ was supposed to groan together with his wife, and various painful acts were performed on him, such as the midwife tying a thread around his penis and tightening it during every contraction [Kabakova 2001: 67]. Nowadays the husband is involved directly in the birth process; he is supposed to join with his wife in breathing, groaning, vocalizing, relaxing and pushing together with her through the contractions:

Igor': Through the contractions, I experienced very special sensations. At first, I hardly realized what was happening to me. The water was full of Svetlana's energy, and it transferred all her feelings, pains and complications to me. Like her, I had abdominal pain. I had back pain. Between contractions, I relaxed as well, all the pain went away, and I felt a degree of relief. [Sargunas 1992]

In some older (not specifically Christian) groups inside the homebirth community, the mother and the father of the baby together eat the placenta both for ritual purposes and for its nutritional value. This practice is viewed as a way of restoring the parents' strength after the birth. However, "Russian Orthodox" midwives suggest burying the placenta in a park or in the countryside under a tree (a ritual without analogy in Russian tradition):

The placenta is to be kept in water, until it is clear whether the baby will have complications. If there are any, you should keep it longer, changing the water from time to time. Just let it live in warm water for a certain length of time. Then the father has to 
bury it in a lonely place, it's the father who must do it. There are some rituals of this kind. These aren't pagan birth rituals, but folk ones. [Alla]

The placenta should be put into the freezer. It was necessary to keep it for some time. Just in case the doctor needed it for analysis. Anyway, we kept it. And then we buried it under a tree, when forty days had passed, I believe. [Tasha]

Some midwives suggest burying the placenta under the corner of a country cottage (dacha), a ritual that did exist in the Russian tradition. Holding a funeral for the placenta, especially on the fortieth day after the birth, that is after the traditional period of ritual transition is over, reflects the popular perception of it as a living creature, a double of the baby itself. Thus, nowadays the placenta still deserves great respect and should be treated carefully in accordance with the rules that apply to human beings.

A number of midwives also preserve the traditional folk practices concerned with the care of the baby; for example, Zhanna Tsaregradskaia, the head of the "Rozhana" center, suggests that the baby should be kept at home for forty days after the birth, and that the parents should avoid contact with visitors. This old custom was originally explained by fear of the evil eye during the period when the child was especially vulnerable before baptism. Tsaregradskaia, however, explains this practice in terms of child psychology, noting that the baby is not yet ready for contact with a wider world full of strangers. She also insists on the necessity of keeping the baby swaddled in a small cradle, asserting that the baby is used to the tightness of the mother's womb and feels uncomfortable when kept in an open space with its arms and legs left free [Tsaregradskaia 2001].(7) However, this point of view is not shared by the majority of midwives, who suggest that babies should be kept naked, and able to move freely, preferably outdoors. From the time they are born they should also swim in a large bathtub and do a great number of specially designed physical exercises.

After the birth, traditional midwives in the past used to "repair" (pravit') the baby in the bathhouse, using special massage and manual therapy. Contemporary midwives are in favor of this. "Oriental" midwives call this practice "baby-yoga," as it follows certain yoga positions.(8) However "Russian Orthodox" midwives reject this name, since they insist on using Russian traditional terms for anything connected with childbirth:

You really shouldn't use those foreign words. There are Russian words for it. [In peasant culture] they used to call it komkat' (crumpling). [Liudmila Vasil'evna] 
As with many other folk techniques, the positions and exercises have had to be reconstructed and reinvented by "spiritual midwives" in accordance with their experience and their understanding of bodily processes.

Once the birth is over, the parents are expected to give the midwife some presents as well as paying her. The gift symbolically represents an exchange of values [Mauss 1950]: in the case of childbirth it is an exchange between the "human" world that receives the baby and the "alien" one, which is compensated via a mediator, the midwife. Money also tends to function symbolically. Irina Martynova noted that people who do not pay their midwife properly may fall sick. Once a family that had treated her badly lost the apartment where they lived and all their savings. On the other hand, the midwife should not feel resentful when she receives less money than she expected. Liudmila Vasil'evna observed that when the midwife is not satisfied with the amount of money she receives, problems including infant deaths will result in her practice. These beliefs demonstrate that the midwife is still perceived as a ritual specialist and a mediator between two worlds.

In Russian traditional culture the cycle of birth rituals incorporating the new member into the community concluded with the baptismal dinner. The "babina kasha" ritual (midwife's porridge) took place over dinner. The midwife made some sweetened porridge, and then collected payment for it from the guests. In this way the community rewarded the local midwife and formally thanked her for providing it with a new member, thus maintaining the fecundity of the community as a whole [Listova 1989: 157-160; Kabakova 2001: 111-115]. Elements of couvade were incorporated into the festival: plenty of salt was put on the father's porridge. In some places, the pot containing hot porridge was tied to his abdomen, and then people smashed it with sticks [Kabakova 2001: 113].

In some of the parenting centers the babina kasha ritual has been preserved. Here is the description of this custom as practiced in the "Dragotsennost" (Gem) parenting school:

Commentator: Kirill is nine days old. He was born here, in the waters of the Black Sea. Today his parents, Stanislav and Tat'iana, have arranged a festival in his honor. Everybody has came to eat some sweetened porridge and drink wine. According to tradition, a father of a baby has to eat the first spoon of porridge. Plenty of salt and pepper is added. Supposedly, by eating this disgusting dish, the father takes upon himself all the troubles the baby might otherwise have had in the future. [Vas'kova 2001] 
The presentation of the baby to the group by the midwife then follows. The presentation is accompanied by the jokes and laughter that in traditional culture were an essential part of all fertility rituals.

In general, the ritual actions performed by contemporary homebirth midwives differ considerably from those of the past. Since the folk tradition of midwifery had been broken, the midwives who entered the profession in the late twentieth century were obliged to re-create tradition. However, in order to lend authority to their practices, they assert that this represents a continuation of older beliefs. They declare that they practice "traditional childbirth," rather than "non-traditional childbirth," the term medical personnel apply to their work. In trying to recreate a monolithic body of tradition, they aim to collect and assemble different pieces of information about traditional midwifery and childbirth. However, using this information in the traditional manner is impossible. Contemporary midwives inevitably have to fill in the lacunae, reinterpret the vague customs of the past and add new ones based on recent scientific advances.

However, though the actual form that various ritual actions took have been altered and reinterpreted, the main archetypal structures of the ritual are intact. When people speak about their feelings as ritual participants, we can observe these patterns. During the ritual, latter-day participants feel deeply integrated into a body of cosmic connections. Thus, midwives' devotion to their work and parents' deep respect for them, the careful treatment of the placenta, as well as the sanctification of maternity and experience of extended states of consciousness during labor, are all examples of archetypal structures at work during the ritual. So, too, is feeling part of humanity or one's country through all its history, speaking directly to God and believing in the invisible ties connecting seemingly distant events. Whether particular elements of traditional customs are being interpreted and reproduced properly or not, the ritual continues to function as a means of transmitting society's values to its members and preserving safely the orderly principles of human life in relation to the universe.

\section{NOTES}

1 This article is a part of a larger project, "The natural childbirth movement in Russia: An anthropological perspective," supported by the Research Support Scheme of the Open 
Society Support Foundation, Grant no.: 997/2000. It is based on material collected during my field research in Moscow and Petersburg in 2000-2001, including participant observation as well as interviews with "spiritual midwives" and people with personal experience of homebirth. These were in-depth unstructured interviews conducted at the interviewee's home or at the parenting school. Before that, in 1995-1999, while working on my dissertation [Belousova 1999], I interviewed another group of seventy women from Petersburg, Moscow and the Russian community in the Estonian cities of Tartu and Tallinn who had given birth in hospital. For the current article, I have also used books and journals published by parenting centers, as well as newspaper articles and documentary movies about homebirth and relevant Russian Web materials. Where the quotation is not attributed, it has been drawn from records of interviews held in my personal archive. I would like to thank all my informants for sharing their experience and deliberations with me.

2 For more detailed data on the history and practice of maternity care in the Soviet Union, see: Levi 1950; Holland and McKevitt 1985.

3 See Nancy Ries for an excellent discussion of these issues in the post-Soviet period [Ries 1997].

4 The icon of the Mother of God, "Help in Birth-giving," is the only icon to portray the Virgin with her hair uncovered.

5 For the purposes of comparison, the cost of birth assistance and rooming in Moscow commercial maternity hospitals ranges from $\$ 400-2500$. While free facilities remain universal, families who can afford these prices prefer the commercial option.

6 Commenting on the semiotics of the lithotomy position in American hospital birth, Robbie Davis-Floyd claims that it is supposed to symbolize the worship of maleconnoted technology ("babies born of science and technology must be born 'up"”) as opposed to women's natural world (which is associated with 'down') [Davis-Floyd 1992: 124].

7 According to students of "national character," popular during the rise of the psychological school in American anthropology (1930s - 1940s), the docile behavior of Russians when dealing with authority, and their sporadic violent "explosions," resulted from them being tightly swaddled as babies [Gorer and Rickman 1949]. This "swaddling 
hypothesis," still receives widespread support, including from some outside the "natural childbirth" community.

$8 \quad$ On baby-yoga positions see: Trunov and Kitaev 1993.

\section{BIBLIOGRAPHY}

Baiburin, A. K. 1993. Ritual v traditsionnoi kul'ture: strukturno-semanticheskii analiz vostochnoslavianskikh obriadov [Ritual in Traditional Culture: The Structural and Semantic Analysis of East Slavic Rites]. St Petersburg: Nauka.

Baranov, D. A. 2001. "Rodinnyi obriad: vremia, prostranstvo, dvizhenie" [Birth rite: time, space and motion]. In E. A. Belousova (ed.), Rodiny, deti, povitukhi v traditsiiakh narodnoi kul'tury [Birth Rites, Children and Midwives in Folk Tradition]. Moscow: Russian State University for the Humanities, pp. 9-30.

Belousova, E. A. 2001. "Prima materia: sotsializatsiia zhenshchiny v rodil'nom dome" [Prima materia: woman's socialization in a maternity hospital]. Trudy fakul'teta etnologii [Research papers from the Ethnology Department]. St Petersburg: European University in St.Petersburg Press. Vol. 1, pp. 73-95.

Bernshtam, T. A. 2000. Molodost' v simvolizme perekhodnykh obriadov vostochnykh slavian: uchenie i opyt tserkvi v narodnom khristianstve [Youth in East Slavic Rites of Passage: Church Doctrine and Experience as Presented in Folk Christianity]. St Petersburg: Peterburgskoe Vostokovedenie.

Charkovskii, Igor' 1999. "Kolybel' chelovechestva ili industriia invalidnosti” [The cradle of mankind or the industry of disability production]. Interview by I. Semenov. Igor' Charkovskii's Website: $\underline{\text { http://charkovsky.chat.ru/frames.htm. }}$

Davis-Floyd, Robbie E. 1992. Birth as an American Rite of Passage. Berkeley-Los Angeles-London: University of California Press.

Dik-Rid, Grantli 1997. Rody bez strakha: original'nyi podkhod k estestvennomu rozhdeniiu rebenka. St Petersburg - Moscow - Kharkov - Minsk: Piter. [Russian translation of Dick-Read, Grantly. 1984. Childbirth without Fear: The Original Approach to Natural Childbirth. New York: Harper and Row.] 
Dobrovol'skaia, V. E. 1998. "Povival'naia babka v obriadakh Sudogodsogo raiona Vladimirskoi oblasti" [The customs surrounding the traditional midwife in the Sudogodskii region of Vladimir oblast']. Zhivaia Starina. No. 2 (18), pp. 19-21.

Firsov, B. and I. Kiseleva (eds) 1993. Byt velikorusskikh krestian-zemlepashtsev. Opisanie materialov etnograficheskogo biuro kniazia V. N. Tenesheva. (Na primere Vladimirskoi gubernii) [The Everyday Life of Russian Peasants]. St Petersburg: Izdatel'stvo Evropeiskogo Doma.

Gaskin, Aina Mei. 1986. Dukhovnoe akusherstvo. Moscow: Akva. [Russian translation of: Gaskin, Ina May 1977. Spiritual Midwifery. Summertown, Tenn.: The Book Publishing Company, 1st ed.]

Gorer, Geoffrey and John Rickman 1949. The People of Great Russia; A Psychological Study. London, Cresset Press.

Holland, Barbara and Teresa McKevitt 1985. "Maternity care in the Soviet Union." In Barbara Holland (ed.), Soviet Sisterhood. Bloomington: Indiana University Press, pp. 145-76.

Ivanov V. V. and V. N. Toporov. 1995a. "Beregini”. In V. Ia. Petrukhin et al., Slavianskaia mifologiia. Entsiklopedicheskii slovar’ [Slavic Mythology. An Encyclopedia.]. Moscow: Ellis Lak, p. 43.

Ivanov V. V. and V. N. Toporov. 1982. "K rekonstruktsii Mokoshi kak zhenskogo personazha $v$ slavianskoi versii osnovnogo mifa" [On the reconstruction of Mokosh' as a female personage in the Slavic version of the core myth"]. In V. V. Ivanov et al. (eds), Balto-slavianskie issledovaniia [Balto-Slavic studies]. Moscow: Nauka, pp. 175-97.

Ivanov V. V. and V. N. Toporov. 1995b. “Mokosh'.” In V. Ia. Petrukhin et al. (eds), Slavianskaia mifologiia. Entsiklopedicheskii slovar’ [Slavic Mythology. An Encyclopedia.]. Moscow: Ellis Lak, pp. 264-65.

Ivanov V. V. and V. N. Toporov. 1995c. "Rod.” In V. Ia. Petrukhin et al., Slavianskaia mifologiia. Entsiklopedicheskii slovar' [Slavic Mythology. An Encyclopedia.]. Moscow: Ellis Lak, p. 335.

Kabakova, G. I. 2001. Antropologiia zhenskogo tela v slavianskoi traditsii [The Anthropology of the Female Body in Slavic Tradition]. Moscow: Ladomir.

Leboie, Fridrikh. 1988. Za rozhdenie bez nasiliia. Moscow: n.p. [Russian translation of: Leboyer, Frédérick. 1984. Pour une naissance sans violence. Paris: Seuil]. 
Levi, M. F. 1950. Istoriia rodovspomozheniia v SSSR [The History of Maternity Care in the USSR]. Moscow: USSR Academy of Medical Sciences.

Levin, Eve. 1991. "Childbirth in Pre-Petrine Russia: canon law and popular traditions”. In Barbara Evans Clements et al. (eds), Russia's Women: Accommodation, Resistance, Transformation. Berkeley: University of California Press, pp. 44-59.

Listova T. A. 1996. “'Nechistota' zhenshchiny (rodil'naia i mesiachnaia) v obychaiakh i predstavleniiakh russkogo naroda" [Female impurity (associated with childbirth and menstruation) in Russian customs and beliefs]. In A. L. Toporkov (ed.), Seks i erotika v russkoi traditsionnoi kul'ture [Sex and the Erotic in Russian Traditional Culture]. Moscow: Ladomir, pp. 151-74.

Listova, T. A. 1989. “Russkie obriady, obychai i poveria, sviazannye s povival'noi babkoi (vtoraia polovina 19 - 20-e gg. 20 v.)" [Russian rituals, customs and beliefs connected with the rural midwife]. In M. M. Gromyko and T. A. Listova (eds), Russkie: semeinyi i obshchestvennyi byt [Russians: Their Family and Social Life]. Moscow: Nauka, pp. 142-71.

Maksimov, S. V. 1994. Nechistaia, nevedomaia i krestnaia sila [The Evil, Unknown and Heavenly Power]. St Petersburg: TOO "Poliset."

Mauss, Marcel. 1950. "Essai sur le don. Forme et raison de l'echange dans les sociétés archaïques". Sociologie et anthropologie. Paris: PUF.

Martynova, Irina. 1999-2002. "Istoriia vodnykh rodov v Rossii” [The history of waterbirth in Russia]. Pts. 1-9. Mailing list Rozhdenie bez nasiliia [Birth without violence]. http://birth.ft.inc.ru. No. 1-82.

Naumenko, G. M. 1998. Etnografiia detstva. Sbornik fol'klornykh i etnograficheskikh materialov [The Ethnography of Childhood. A Collection of Folk and Ethnographic Materials]. Moscow: Belovod'e.

Nekrylova, A. F. 2000. "Sviataia Varvara v narodnoi kul'ture” [St. Barbara in folk culture]. In M. L. Lur'e (ed.), Traditsiia v fol'klore i literature: stat'i, publikatsii, metodicheskie razrabotki prepodavatelei i uchenikov Akademicheskoi gimnazii Sankt-Peterburgskogo gosudarstvennogo universiteta [Tradition in Folklore and Literature]. St Petersburg: Akademicheskaia gimnaziia Sankt-Peterburgskogo gosudarstvennogo universiteta, pp. 52-65.

Oden, Mishel' 1994. Vozrozhdennye Rody. Moscow: Akva. [Russian translation of Odent, Michel. 1976. Bien naître. Paris: Seuil.] 
Ovchinnikova, Ol'ga. 1998. Chto nam stoit dom postroit': traditsionnaia krestianskaia kul'tura kak osnova postroeniia sovremennykh russkikh populiarnykh tekstov i kul'turnoi praktiki. [Traditional Russian culture as a basis for contemporary Russian popular texts and cultural practice]. Tampere: Tampereen Yliopisto.

Popov, G. 1996. "Russkaia narodno-bytovaia meditsina" [Russian popular medicine]. In M. Toren (ed.), Russkaia narodnaia meditsina i psikhoterapiia [Russian Popular Medicine and Psychotherapy]. St Petersburg: Litera.

Postnova, Iu. V. "O rabote s golosom v rodakh" [About working with the voice during labor]. Web site of "Dragotsennost"” parenting school http://www.gemschool.ru/art post2.html

Rei Sondra, 1985. Ideal'noe rozhdenie. Abbreviated translation by M[ikhail] T[runov]. Moscow. [Russian translation of: Ray, Sondra. 1985. Ideal Birth. Berkeley: Celestial Arts.] Ries, Nancy. 1997. Russian Talk: Culture and Conversation during Perestroika. Ithaca and London: Cornell University Press.

Sargunas Tat'iana, Sargunas Alexei (eds.). 1992. Akva: besedy s Igorem Charkovskim. Rasskazy o rodakh v vode [Aqua: Conversations with Igor Charkovskii. Waterbirth stories]. Moscow: T-Oko.

Sargunas, Aleksei. 1992. Novyi Svet: voda i rozhdenie [Novyi Svet: Water and Childbirth]. Documentary film. Aleksei Sargunas (dir.). Moscow: Akva.

Sargunas, Tatiana. 1998. "Ritual i estestvennye rody" [Ritual and natural childbirth]. Paper given at a round table discussion: "Povitukhi, rodiny, deti v traditsionnoi kul'ture" [Midwives, birth rites and children in traditional culture]. Moscow: Russian State University for the Humanities.

Sedakova, I. A. 1999. "Krik v poveriiakh i obriadakh, sviazannykh s rozhdeniem rebenka" [Crying in childbirth beliefs and customs]. In S. M. Tolstaia (ed.), Mir zvuchashchii i molchashchii: semiotika zvuka i rechi v traditsionnoi kul'ture slavian [The Audible and the Silent World: The Semiotics of Sound and Speech in Traditional Slavic Culture]. Moscow: Indrik.

Slashchev, V. V. 1995. “Paraskeva Piatnitsa.” In V. Ia. Petrukhin et al., Slavianskaia mifologiia. Entsiklopedicheskii slovar' [Slavic Mythology. An Encyclopedia.]. Moscow: Ellis Lak, pp. 297-98.

Stepanova, E. 2001. "Bereginia.” Chadushki. Pravoslavnaia gazeta dlia detei i roditelei. [Progeny. The Russian Orthodox newspaper for children and parents.] No. 2 (7), December 2001. 
Tolstoi, N. I. 1995. “Bereginia.” In N. I. Tolstoi et al. (eds), Slavianskie drevnosti. Ethnolingvisticheskii slovar'. [Slavic Antiquities. An Ethno-linguistic Dictionary]. Vol. 1. Moscow: Mezhdunarodnye otnosheniia, pp. 155-56.

Trunov, Mikhail and Leonid Kitaev. 1993. Ekologiia mladenchestva: pervyi god [Infant Ecology: The First Year of Life]. Moscow: Ecologiia Sem'i.

Tsaregradskaia, Zh. V. 2001. Psikhologiia novorozhdennogo [The Psychology of the Newborn]. Moscow: n.p.

Vas'kova, Natal'ia 2001. Podvodnyi roddom [The Underwater Maternity Hospital]. Documentary film. Natal'ia Vas'kova (dir.).

Vlaskina, T. Iu. 1998. "Donskie bylichki o povitukhakh" ['True stories' about traditional midwives in the Don region]. Zhivaia Starina. No. 2 (18), pp. 15-17.

Vlaskina, T. Iu. 2001. "Mifologicheskii tekst rodin" [The mythological text of the birth rite]. In E. A. Belousova (ed), Rodiny, deti, povituhhi v traditsiiakh narodnoi kul'tury [Birth Rites, Children and Midwives in Folk Tradition]. Moscow: Russian State University for the Humanities, pp. 61-78.

Zharkin, N. A. "Dukhovnoe akusherstvo i pravoslavie v Rossii" [Spiritual midwifery and Orthodoxy in Russia]. hltp://www.mama.ru/birth/zha03.htm 